\title{
Journal of Economy Culture and Society
}

ISSN: 2602-2656 / E-ISSN: 2645-8772

Kuramsal Makale / Theoretical Article

\section{Günümüz Çalışma Rejiminde Uykunun İkircikli Konumu: Kavramsal Bir Tartışma}

\section{The Ambivalent Position of Sleep within the Current Work Regime: A Conceptual Discussion}

\author{
Emir KURMUŞ ${ }^{1}$ (D, Çağatay TOPAL ${ }^{2}$ (c)
}

'Arş. Gör. İstanbul Üniversitesi, Siyasal Bilgiler Fakültesi, Siyaset Bilimi ve Kamu Yönetimi Bölümü, İstanbul, Türkiye

${ }^{2}$ Doç. Dr. Orta Doğu Teknik Üniversitesi, Sosyoloji Bölümü, Ankara, Türkiye

ORCID: E.K. 0000-0002-0775-5663;

Ç.T. $0000-0001-5323-8440$

\section{Corresponding author:}

Çağatay TOPAL,

Orta Doğu Teknik Üniversitesi, Fen Edebiyat Fakültesi, Sosyoloji Bölümü, Ankara, Türkiye

E-mail: catopal@metu.edu.tr

Submitted: 23.10 .2021

Revision Requested: 20.01.2021

Last Revision Received: 24.05.2021

Accepted: 19.06 .2021

Published Online: 05.11.2021

Citation: Kurmus, E., \& Topal, C. (2021). Günümüz çalışma rejiminde uykunun ikircikli konumu: Kavramsal bir tartışma. Journal of Economy Culture and Society, 64, 357-376. https://doi.org/10.26650/JECS2020-815618 öz

Uyku son yıllarda yaygınlaşan bir şekilde tıbbi ve psikolojik araştırmaların, medyada çeşitli haberlerin konusu olmaktadır. Bu çalışma, uykuya yönelik artan ilginin altında bazı sosyo-ekonomik süreçlerin olduğunu iddia etmekte; günümüz kapitalist çalışma rejimindeki beden, iş ve gündelik yaşamın ritimleri arasındaki ilişki üzerinden uykuyu inceleyen bir analiz çerçevesi önermektedir. Bu çerçeve içerisinde hem günümüz toplumundaki uyku pratikleri ve uykuya bakıs hem de günümüz kapitalizminin bazı yapısal süreçleri ve çelişkileri zaman baskısı kavramı etrafında tartışılmaya çalışılmıştır. Kapitalizmin güncel koşullarındaki zaman deneyimini temel olarak çalışma yaşamındaki esnekleşme ve sosyal yaşamın hızlanması şekillendirmektedir. Zorunluluklarla şekillenen arzulardaki hızlanma ve esnekleşme yeni bir tür beden disiplinini zorunlu kılmaktadır. Süre olarak çalışanların yaşamının çok önemli bir bölümünü kapsayan uyku bir yandan kısmen ya da tamamen feragat edilebilir bir pratik haline gelirken, bir yandan da iş ve gündelik yaşamdaki etkinliklerin verimli bir şekilde devamı açııından kritik bir yerde durmaktadır. Bu çalışmanın amacı uykunun bu çelişkili konumunu esas olarak Hartmut Rosa'nın sosyal hızlanma kavramından hareket ederek, hızlanma, esnekleşme ve zaman baskısı üçlüsünün oluşturduğu ve temelde kapitalizmin tanımladığı sosyal zemin üzerinden açıklamaktır.

Anahtar Kelimeler: Uyku, Kapitalizm, Sosyal hızlanma, Esnek çalışma rejimi, Zaman baskısı

\section{ABSTRACT}

Sleep is attracting increasing medical and psychological research interest as well as media interest. This study investigates the socio-economic processes behind this growth in interest. It proposes an analytical framework that examines sleep in the relationships among the body, work, and the rhythms of everyday life within the constraints of today's capitalist work regime. In this framework, the concept of time pressure is significant for understanding practices and approaches to sleep, as well as the structural processes and contradictions of contemporary 
capitalism. Having a work life and accelerating one's social life are the main determinants of time experience. While sleep, which is a very important part of an employee's life, becomes limited or restricted, it is nevertheless essential for the sake of efficiency and continuing activity in business and daily life. This study investigates the ambivalent position of sleep with reference to Hartmut Rosa's concept of social acceleration. This ambivalent position is found to be constructed by the trio of acceleration, flexibility, and time pressure, and it is essentially defined by capitalism.

Keywords: Sleep, Capitalism, Social acceleration, Flexible work regime, Time pressure

\section{EXTENDED ABSTRACT}

This study proposes a conceptual framework within the discipline of sociology to the problem of sleep, accepted as a natural activity of human beings. Based on Hartmut Rosa's $(2009,2013)$ concept of social acceleration, this study focuses on the ambivalent position of sleep, revealed within the tripartite relationship of social acceleration, flexible working regimes, and time pressure. The claim of the study is that this position is determined within the interaction of deceleration and acceleration. Sleep, perhaps the most important deceleration practice in human life, has both preventive and supportive functions in capitalist acceleration. The combination of these two functions, which seem to be in opposition, indicates the ambivalent position of sleep at the present time.

The first contemporary sociological studies on sleep were shaped by the medicalization debate. Kroll-Smith and Gunter (2005, p. 363) found a constructed discourse on healthy sleep, indicating how sleep should be shaped. Emphasizing that insomnia poses risks to individual health, public health, and the economy, they showed that a new truth about sleep was being constructed. However, Kroll-Smith and Gunter do not address the question of why this health discourse was constructed. The proliferation of a health discourse on sleep indeed points to structural transformations and problems. This study argues that increased discourse on sleep is not a coincidence, and this increase is associated with changes in temporal norms and the structures of economic and social life. Sleep practice can be used not only to examine the position of sleep in today's society, but also to examine the basic structures of the society in question itself and the time experience that they generate.

Time is the precondition for thought to develop on the stability, contradiction or transformation within social order and society (Šubrt \& Cassling, 2001, p. 212). Without accounting for the dimension of time, it is impossible to understand the features and transformations of modernity and capitalism (Rosa, 2009, p. 79). It is important to understand the temporal structures and time-use practices to establish the necessary link between the macro and micro dimensions of social experience. Nevertheless, according to Rosa and Scheuerman (2009, p. 15), the mainstream social sciences are afraid to underline the need for a serious analysis of social temporality. Although these structures themselves have opposed or contradictory consequences, temporal structures can be considered to be a point of connection for the integration and coordination of social and individual perspectives. The integration between macro and micro rhythms does not arise or function automatically. For this integration to properly impose itself, a power network that feeds and functions in different fields is necessary. This marks a line that expresses the close connection between the personal and the social. Ignoring dominant temporal norms and social rhythms can lead to social sanctions and exclusion. Thus, the question "Why do I use my time the way I use it, and how should I use it?" is among the most fundamental social and political questions, both in terms of analyzing existing structures and developing the perspective of transforming this structure (Rosa \& Scheuerman, 2009, p. 16).

This article offers a conceptual framework according to which the rhythms of the body can be dealt with in relation with the rhythms of capitalism. In this context, both the effort to improve harmony and 
coordination between rhythms and conflicts and contradictions are emphasized. This study proposes a framework that does not ignore the distinctions between the historicity of social time, as conditioned by the mode of production, and the experiences of different social groups in different places (see Colley, Henriksson, Niemeyer, \& Seddon, 2012). The basic concept used for this purpose is that of social acceleration, as developed by Hartmut Rosa $(2009,2013)$. Another process related to acceleration, to be discussed over the time theme, is the flexibility of the working regime. This article will primarily examine acceleration and flexibility in the context of time pressure. This discussion is undertaken to show that the triad of acceleration, flexibility, and time pressure are the defining elements of today's capitalism. The article will then seek to make sense of the position of sleep in capitalism for the result of these three processes. Finally, the ambivalent nature of the position of sleep in the interaction of deceleration and acceleration will be analyzed. This study will thus provide a framework that places sleep within processes of acceleration, flexibility, and time pressure, and thus contribute to understanding the ambivalent status of sleep in capitalism in the context of the intertwined relationship between deceleration and acceleration. 


\section{Giriş}

Uyku konusu Türkiye'de ve dünyada kişisel gelişim literatüründe, gündelik sohbetlerde, bilimsel araştırmalarda ve medyada giderek artan oranda kendine yer bulmaktadır. Daha iyi bir uykunun nasıl sağlanacağı, sağlıklı uykunun bileşenleri ve zaman kullanımı içinde uykunun gerekliliği ve etkileri konusundaki araştırmalar ve haberler sıkça göze çarpmaktadır. Dünyada özellikle 1990'ların sonundan itibaren uyku üzerine yapılan tıbbi çalışmalar artmış, bu konuda uzmanlaşmış tıbbi kurumlar açılmış, uyku ile ilgili ilaçların sayısında ciddi artışlar olmuş, yalnızca uyku pratikleri ve problemlerini araştıran uyku klinikleri faaliyete geçmiştir. Türkiye de bu eğilimi açıkça yansıtan ülkelerden biridir. Yüksek Öğretim Kurumunun (YÖK, 2019) tez veri tabanı referans olarak alınırsa, Türkiye'de 2000 ile 2019 yılları arasında doğrudan uyku ile ilgili 900'den fazla lisansüstü tez yazılmıştır. 2000 yılı öncesinde bu sayı 45 civarındadır ve bu tezlerin çoğu 90'ların ikinci yarısında tamamlanmıştır. Uyku konusundaki bu araştırmalarda çoğunlukla tıp, biyoloji, eczacılık, psikoloji ve nöroloji gibi bilimsel disiplinlerin içinde sosyallikten yalıtılmış birey temelli analizler yürütülmüştür. Uykunun toplumsal boyutu yalnızca tıpla ilgili bilim dallarınca değil sosyal bilimciler tarafından da göz ardı edilmiş; bu çalışma alanı uykunun salt fizyolojik ve doğal bir aktivite olduğu varsayımıyla doğa bilimlerine terk edilmiştir (Marinache, 2015, s. 18-22; Chatzitheochari ve Arber, 2009, s. 32-33). Bu çalışmanın amacı, insanın "doğal aktivitesi" kabul edilerek sosyal bilimler tarafından ihmal edilen uyku sorunsalına sosyoloji disiplini içinden bir kavramsal çerçeve önermektir. Çalışma Hartmut Rosa’nın $(2009,2013)$ "sosyal hızlanma (social acceleration)" kavramından hareketle uykunun günümüz kapitalizm koşullarını tanımlayan sosyal hızlanma, esnek çalışma rejimleri, zaman baskısı üçlü ilişkisinde açığa çıkan ikircikli konumuna odaklanmaktadır. Çalışmanın iddiası bu konumun yavaşlama ve hızlanma etkileşiminde belirlendiğidir. İnsan hayatındaki en önemli yavaşlama pratiği olarak görülebilecek uyku kapitalist hızlanma için hem engelleyici hem de destekleyici işlevlere sahiptir. Birbiriyle çelişkili gibi görünen bu iki işlevin birlikteliği uykunun günümüzdeki ikircikli konumunu göstermektedir.

Tıbbın ve bağlantılı disiplinlerin uykunun bireylerin fiziksel, zihinsel sağlıkları ve kapasiteleri üzerindeki etkisine yaptığı vurgular uyku yoksunluğunun yarattığı sosyal problemlerin araştırılmasına alan açmıştır (Marinache, 2015, s. 21). Uyku üzerine ilk önemli çağdaş sosyolojik çalışmalar uykunun tıbbileştirilmesi tartışması etrafında şekillenmiştir. Kroll-Smith ve Gunter (2005, s. 363) uykuya yönelik ilgideki artışı söylem analizi çerçevesinde ele alıp, uykuya dair sağlık üzerinden bir söylem inşa edilip bunun etrafında insanların uyku pratiklerinin biçimlendirilmeye çalışıldığını savunmuşlardır. Uykusuzluğun hem bireysel sağlı hem halk sağlığı hem de ekonomi için bir risk oluşturduğunu vurgulayarak inşa edilen tek bir söylemin, birçok makro ve mikro kanaldan yayılarak uykuyla ilgili yeni bir "hakikat" inşa edildiğini ve bu hakikat etrafında kişilerin uyku pratiklerinin belirlendiğini ifade etmişlerdir.

Sağlıklı uykunun nasıl olması gerektiğine dair farklı görüşler öne sürülse de çoğunlukla kabul gören 7-8 saatlik, sessiz bir ortamda ve rahat bir yatakta gerçekleştirilen kesintisiz bir gece uykusudur. Yine de uyku üzerine tek bir söylemden söz etmek mümkün değildir. Birbiriyle çelişen farklı sağl1k söylemleri farklı kişilerce benimsenebilmektedir. Uykuyla ilgili sağlık söylemindeki yaygınlaşma gerçekten de bazı yapısal dönüşüm ve sorunları işaret etmektedir. Bu çalışma, uyku üzerine söylemlerdeki artışın bir tesadüf olmadığını ve bu artışın ekonomik ve sosyal yaşamın zamansal normları ve yapılarında belli değişikliklerle ilişkili olduğunu savunmaktadır. Bu çalışmanın amaçlarından biri, insanların yaşam süresinin yaklaşık üçte birini kapsayan uyku pratiklerinden hareketle günümüz kapitalizminde ortaya çıkan zaman deneyimini ve bunun yapı- 
sal kökenlerini gösterebilmektir. Diğer bir deyişle, uyku pratiği, yalnızca uykunun günümüz toplumundaki konumunu inceleyebilmek için değil aynı zamanda söz konusu toplumun temel yapılarını ve bunların ürettiği zaman deneyimini inceleyebilmek için de bir araçtır. Uyku pratikleri tarihsel olarak farklılık göstermektedir ve tarihsel sosyal düzeni ve dönüşümleri anlayabilmek için işlevsel olarak kullanılabilir.

20. yüzyılın ilk yarısında sosyoloji ve antropoloji alanında çok önemli eserler vermiş Marcel Mauss (1973), "Beden Teknikleri” başlıklı makalesinde uyku konusuna da değinmiş nadir sosyal bilimcilerden biridir. Ona göre, uyku bedensel bir eylem olduğundan, biyolojik bir aygit bu beden tekniği için bir öngerekliliktir. Bu tekniğin biyolojik yankıları olacaktır ama bu aygıt (beden) tekniğin sebebi değildir, bir “dişli-çark (cogwheel)"tır. Bu tekniğe uyum sağlarken birey fizyolojisi ve psikolojisi önemlidir fakat bu tekniğin kendisi yaşam koşulları tarafından yönetilir. Kısacası, uykuyu analiz ederken karşılaştığımız şey fiziksel, psikolojik ve sosyolojik olanın bir aradalığıdır. Dolayısıyla da sosyal ilişkilerinden yalıtılmış birey, uyku araştırmalarında tek analiz birimi olmamalıdır (Mauss, 1973, s. 77, s. 85-86).

Lefebvre (2004) Ritimanaliz isimli eserinde Mauss'un izinden giderek bu sosyalliği açar ve tarihselliğe oturtarak kapitalizmle ilişkilendirir. Beden ve kapitalizm ilişkisini zaman boyutu üzerinden kurar. Mauss gibi Lefebvre de beden analizini fizyoloji, tıp ve psikoloji gibi alanların egemenliğinden kurtarmaya çalışır. Fakat bu alanları tamamen dışlamak yerine, ritimanalizinde bu disiplinleri de içermeyi öneren geniş bir perspektif sunar. Bu geniş perspektifi sağlayan temel disiplin sosyolojidir. Lefebvre (2004, s. 16-20) bedeni yalnızca sosyal bütünlüğün içindeki bedeni anlayabilmek için değil sosyal bütünlüğün kendisini anlayabilmek için de temel bir analiz birimi olarak ele alır. Bedenin, doğanın, kapitalizmin, gündelik yaşamın ritimlerinin birbiriyle nasıl etkileşim ve zaman zaman çelişki halinde olduğunu tartışan Lefebvre'in çerçevesi, günümüz kapitalizmiyle uyku arasındaki ilişki üzerine düşünürken önemli bir kuramsal dayanak oluşturur.

Lefebvre'e (2004, s. 43-44) göre her insan bedeninin acıkma, susama, dışkılama ve uyku gibi biyolojik ritimleri vardır. Bu biyolojik ritimler sosyallik içerisinde sürekli olarak yeniden üretilir ancak sosyal yaşamın kendisi durağan olmadığı için, bu bedensel pratikler de dönüşüme uğrayabilir. Çoğu zaman, insanlar bu ritimler üzerine düşünerek hareket etmez ya da buradaki küçük dönüşümleri fark etmez; çünkü bu ritimler sosyallik içinde verilidir. Farkında olmama hali düzensizliklerden dolayı sıkıntılar yaşayana ya da derin dönüşümlere kadar sürer (Lefebvre, 2004, s. 77). Uyku meselesinin günümüzde giderek artan oranda üzerine daha çok düşünülen bir konu olmasının toplumun böyle bir tarihsel uğrakta bulunmasından kaynaklandığg düşünülebilir. Çalışanların bedenleri yalnızca meta üretmez, aynı zamanda belli bir zaman disiplinine göre iş yeri ve iş yeri dişındaki kendi bedensel pratiklerini de üretir ve dönüştürür. Bedenin ve bir bedensel pratik olarak uykunun günümüz kapitalizmindeki konumunu inceleyebilmek için öncelikle kapitalizmdeki güncel dönüşümler zaman boyutu üzerinden tartışılmalıdır.

Zaman, toplumsal düzen ve toplum içindeki istikrar, çelişki veya dönüşüm üzerine geliştirilecek herhangi bir düşüncenin önkoşuludur (Šubrt ve Cassling, 2001, s. 212). Toplumsal ve siyasal analize zaman boyutu eklenmediği sürece modernlik ve kapitalizmin özelliklerini ve dönüşümlerini tam olarak anlayabilmek mümkün değildir (Rosa, 2009, s. 79). Zamansal yapılar ve zaman kullanım pratikleri, toplumsal deneyimin makro ve mikro boyutları arasında zorunlu bağlantıyı kurmayı sağlayacak önemli noktalardır. Yine de Rosa ve Scheuerman'a (2009, s. 15) göre, ana akım sosyal bilimler toplumsal zamansallığın ciddi bir analizine olan ihtiyacın altını çizmeye çekinmektedir. Her ne kadar bazen bu yapıların kendisi tam tersi ya da çelişkili sonuçlara varsa da zamansal yapılar toplumsal ve bireysel perspektiflerin bütünleşmesi ve koordinasyonu için bir 
bağlantı noktası olarak düşünülebilir. Makro ve mikro ritimler arasındaki bütünleşme kendiliğinden ortaya çıkıp işlemez. Bu bütünleşmenin kendini empoze edebilmesi için farklı alanlardan beslenen ve bu alanlarda işleyen bir iktidar ağı gerekir. Baskın zamansal normları ve toplumsal ritimleri yok saymak çeşitli yaptırımlara ve toplumsal dışlanmaya yol açabilir. Böylece "zamanımı neden böyle kullanıyorum ve nasıl kullanmalıyım” soruları hem var olan yapıyı analiz etmek hem de bu yapıyı dönüştürme perspektifini edinebilmek için en temel sosyal ve politik sorular haline gelir (Rosa ve Scheuerman, 2009, s. 16). Zaman üzerine çatışmaları analiz ederken, zamanın iktidarın merkezi boyutlarından biri olduğu görülür. İktidar önceliklerin, hızların, başlangıçların ve sonların kurgulandığı zaman sistemleri içerisinde açığa çıkar (Nowotny, 1994, s. 105).

$\mathrm{Bu}$ makalede bedenin ritimlerinin kapitalizmin ritimleriyle ilişkili bir şekilde ele alınacağ bir analiz çerçevesi sunulmaya çalışılmıştır. Bu çerçevede yalnızca ritimler arasındaki uyum ve koordinasyonu geliştirme çabası değil aynı zamanda çatışma ve çelişkiler de vurgulanmaktadır. $\mathrm{Bu}$ çalışma, üretim tarzı tarafından koşullandırılan toplumsal zamanın tarihselliği ile farklı toplumsal grupların farklı mekanlarda yaşadığı deneyimler arasındaki ayrımları göz ardı etmeyen bir çerçeve önerme amacındadır (bkz. Colley ve ark., 2012). Kapitalizmin farklı dönemlerde fark$l_{1}$ işleyişleri ve farklı etkileri olduğunu kabul etmekle birlikte, bu farkları incelemek bu çalışmanın kapsamını fazlasıyla aşacağından yalnızca günümüz kapitalizminde görülen temel eğilimlere zaman boyutu üzerinden değinilecektir. Bu amaçla kullanılan temel kavram Hartmut Rosa (2009, 2013) tarafından geliştirilmiş “sosyal hızlanma"dır. Hızlanmayla ilişsili, zaman teması üzerinden tartışılacak diğer süreç çalışma rejiminin esnekleşmesidir. Makale öncelikle hızlanma ve esnekleşme süreçlerini zaman baskısı bağlamında irdeleyecektir. Bu irdelemenin amacı hızlanma, esnekleşme ve zaman baskısı üçlüsünün günümüz kapitalizminin tanımlayıc1 unsurları olduğunu gösterebilmektir. Makale, sonrasında uykunun kapitalizm içindeki konumunu söz konusu üç sürecin bileşkesinde anlamlandırmaya çalışacaktır. Son olarak uykunun konumunun bu bileşkedeki yavaşlama ve hızlanma etkileşiminde açığa çıkan ikircikli niteliği analiz edilecektir. Çalışma bu anlamda uykuyu hızlanma, esnekleşme ve zaman baskısı süreçlerinin ortasına konumlandıran, bu konumlandırma sayesinde ortaya çıkan yavaşlama ve hızlanmanın iç içe geçmiş ilişkisi bağlamında uykunun kapitalizm içindeki ikircikli statüsünü anlamaya katkı verecek bir çerçeve sunmuş olacaktır.

\section{Sosyal Hizlanma}

Hızlanma, basitçe, bir birim zamanda girdilerin ve çıktıların, gerçekleşen olayların ve durumların sayısı ve yoğunluğunun artması anlamına gelir (Zherebin, Vershinskaia ve Makhrova, 2015, s. 197). Rosa (2013) modern toplumu hizlanma toplumu olarak tanımlar ve sosyal hizlanmayı üç ayrı kategoride ele alır. Bu üç kategorinin üç temel itici gücü vardır. Sosyal hızlanmanın en görünür biçimi teknolojik süreçlerde karşımıza çıkar (Rosa, 2009, s. 82). Teknolojik hızlanma, taşımacılık alanında bir saatte kat edilen kilometrede, iletişim alanında bir mikro saniyede iletilen bilgide, üretim alanında bir günde, ayda ya da yılda üretilen maddi çıktıdaki artışla somutlaştırılabilir (Rosa, 2017, s. 35). Bunu hem teknolojide yaşanan sürekli değişim hem de teknolojinin getirileriyle yaşanan hızlanma üzerinden okumak mümkündür. Fakat teknolojik hızlanmanın bir sebep değil bir sonuç olduğu da iddia edilebilir. Her koşulda, teknolojik hızlanmanın temel itici gücü Rosa'ya (2013) göre ekonomidir. Kapitalist üretim tarzında, işçilerin üretkenliğini artırmak, bir birim zamanda işçilerden elde edilen çıktıyı maksimize etmek anlamına gelir (Rosa, 2009, s. 89). Bir metanın döngü zamanını kısaltmak hem o metanın daha kısa sürede üretimine hem de daha kısa sürede dağıtımı ve satışına işaret eder. Böylece kâr daha hızlı elde edilir ve yeni yatı- 
rımlar için kullanılabilecek sermaye daha hızlı bir şekilde geri döndürülür. Bu hızlı döngü süreçleri teknolojik yenilikleri takip etmeyi ve bunun öncüsü olma çabasını kaçınılmaz kılar; çünkü teknoloji üretim, dağıtım, tüketim ve para döngülerini hızlandırmada kilit bir öneme sahiptir (Rosa ve Scheuerman, 2009, s. 5, s.21; Rosa, 2009, s. 88-89). Hızlanma, bir şirketin diğer şirketlerle girdiği rekabette avantajlı olabilmesi için elzemdir. Bu yüzden şirketin işlerini yapan çalışanların da hızlanması beklenir. Hem işe girebilmek hem de işe girdikten sonra o işte kalabilmek için bir işçinin hızlanmanın gerekliliklerine fiziksel ve zihinsel olarak uyması bir zorunluluktur.

Kapitalist toplumlarda yaşamın hızlanması yeni bir tema değildir. Bu konudaki tartışmalar ve analizler sanayileşmenin başlangıcına kadar götürülebilir (Roxburgh, 2002, s. 121). Yeni örgütsel biçimlerle, yeni teknolojilerle ve sürekli üretilen yeni yaşam biçimleriyle metaların, sermayenin, bilginin ve bedenlerin, dolayısıyla da ekonomik yaşamın daha hızlı işlemesi sağlanmaya çalışılır. Döngü zamanlarını azaltma çabası kapitalizmin içkin bir özelliğidir (Jessop, 2009, s. 142; Scheuerman, 1999, s. 1891-1892). Ancak günümüzde döngü zamanlarını kısaltma, zaman denetimini daha mikro düzeyde gerçekleştirme, mekânla ilişkili sınırlı1ıkları önemli oranda aşma olanakları arttığı için hızlanma çok daha baskın ve görünür hale gelmiştir (Yılmaz, 2008, s. 159). Bilgi, iletişim ve ulaşım teknolojilerindeki gelişmeler bu süreci hızlandırmaktadır. Küresel piyasanın entegrasyonunun önündeki engeller kalktıkça kapitalizmin hızı artmakta; şirketler de rekabette kendilerine avantajlı bir yer bulabilmek için sermaye birikimini ve döngü zamanlarını azaltma yönünde sürekli bir baskı hissetmektedir (Jessop, 2009, s.136-142).

Sosyal hızlanma kavramının içerdiği ikinci kategori yaşam temposunun hızlanmasıdır. Bu hızlanma kategorisi nesnel olarak bir faaliyet ya da deneyime ayrılmış zaman dilimlerinin ve bir etkinlikten diğerine geçme süresinin kısalmasını veya bunların artan ölçüde eşanlı olarak yapılmasını ifade eder. Öznel olarak ise bireylerin daha fazla zaman kıtlığ 1 yaşamasını, yaşamın hızlı akışına yetişmekte zorlanmalarını ve daha fazla hızlanmaya zorlanmalarını anlatır (Rosa, 2013, s. 78-79). Zaman baskısı verili görev ve isteklere ayrılabilecek zamansal olanaklarla bunları düzgün bir şekilde yapmak için gereken zaman arasındaki uyumsuzluğa işaret eder. Bir başka deyişle somut olarak sahip olunan zamanın yapılacaklar listesinin gerçekleştirilmesi için yeterli olmaması hissiyatı ve durumudur (Rosa, 2017, s. 25). Bu baskıyı azaltmak için eylemleri hızlandırmak, molaları azaltmak veya zaman alıcı etkinliklerin yerine daha hızlı gerçekleştirilebilecek etkinlikleri koymak gibi stratejiler kullanılır (Rosa, 2013, s. 122). Teknoloji bir yandan bu bask1nın azaltılmasını sağlarken öte yandan tahayyül edilebilir firsatları artırır ve farazi imkânları gerçek seçeneklere dönüştürür (Rosa, 2017, s. 25-28). Rosa (2017, s. 41) bu durumu teknolojinin "zamansal geri tepme etkisi (temporal rebound effect)" olarak kavramsallaştırır. Mekânsal sınırlılıkları birçok alanda büyük ölçüde ortadan kaldıran cihazlar sayesinde gerçekleştirilmesi potansiyel olarak artık mümkün olan beklentilerin sayısı artar. Rosa'ya (2009, s. 85-87) göre hızlanma toplumu, zamansal rahatlama sağlaması gereken teknolojik hızlanma ile zaman kıtlığının eş zamanlı olarak bulunduğu toplumdur.

Bu hızlanma formunun temel itici gücü kültüreldir. Kültürel güç doğrudan modernitenin baskın kültürel programı ile ve onun "iyi yaşam (good life)" kavramı ile ilişkilidir. Modernite bireylere farklı deneyimler sunarak dolu bir yaşam vaat eder. Bu vaat aynı zamanda modern dünyanın sunduğu birçok olanak ve seçenekten mahrum kalma korkusu yaratır (Rosa, 2013, s. 134). "İyi yaşam" bireylerin yetenek ve potansiyellerinin mümkün olan en yüksek derecede geliştirilmeye çalışılması yoluyla oluşacak kendini-gerçekleştirme idealini içerir. Bu yüzden bireyler yaşam sürelerini mümkün olduğunca yoğun geçirmelidir (Rosa, 2013, s. 181-182). Sosyal yaşamdaki hızlanma, gün geçtikçe seçenekleri artırır. Bireyler için bu seçenekleri değerlendirebilmenin ka- 
çınılmaz yolu yaşamlarını hızlandırmaktır. Sosyal yaşamın hızının artması ve bireylerin bu hıza uyum sağlayabilmek amacıyla kendilerini hızlandırması karşılıklı olarak birbirini besleyerek sosyal yaşamın hızını daha da artırır (Rosa, 2009, s. 91-92). Söz konusu koşullarda hızlı yaşamak bir strateji olarak belirir. Bununla birlikte, seçenekler bir bireyin yaşam sürecince gerçekleştirilebileceğinden çok daha fazladır ve seçeneklerin sayıları giderek artmaktadır. Dolayısıyla potansiyel olarak gerçekleştirilebilecek deneyimler ve seçenekler aslında oransal olarak giderek azalmaktadır. Bireyler sosyal ve ekonomik yaşamdan dışlanmamak için giderek hızlanmak, değişimin hizını yakalamak zorundadır (Rosa, 2009, s. 88, s. 98).

Sosyal hızlanmanın üçüncü kategorisi olan toplumsal değişimin hızlanması, eylemleri yönlendiren toplumsal çerçevelerin değişme hızındaki artışı ve istikrar sağlayıcı kurumsal yapıların var olma sürelerinin kısalmasını ifade eder (Rosa, 2013, s. 76, s. 113). Bu aralıksız değişme sürecinde hangi seçeneklerin daha değerli hale geleceğini kestirebilmek zorlaşır (Rosa, 2009, s. 88, s. 98). Başka bir ifadeyle, şimdinin güvenilirliği ve geleceğin öngörülebilirliği azalmaktadır. Bu durum bireyleri ve her türden örgütlenmeyi, gelecek beklentilerini sürekli gözden geçirmeye ve sıkça değişen durumlara göre yenilemeye iter (Rosa, 2013, s. 116-117). Rosa'nın (2013, s. 134) yapısal olarak tarif ettiği üçüncü itici güç hem toplumsal sistemler hem de birey düzeyinde toplumsal değişimin hızlanmasına uyum sağlama zorunluluğuna işaret eder. Modern toplum işlevsel farklılaşma üzerine kuruludur. Toplumsal sistemdeki değişikler sürekli hale geldiği ve hızlandığ 1 için, alt sistemler de sürekli olarak kendilerini uyumlulaştırarak diğer sistemlerle senkronizasyon sağlayabilmek için hızlanmaktadır. Bir toplum daha karmaşık hale geldikçe zamansal kaynaklar da daha kısıtlı hale gelir. Var olan bilgi birikimi süreklileşen bir geçersizleşme tehdidi altında kalır ve toplumsal sistemdeki hızlı değişiklikler sürekli bir "kaygan zemin (slipping slope)" hissi yaratır (Rosa, 2013, s. 134, s. 186). Geleceği belli ölçülerde tahmin edip beklentileri buna göre ayarlamak ve uzun dönemli planlamalar yapmak günümüz hızlanma toplumunda giderek zorlaşır (Rosa, 2013, s. 189-190). Geç modernitede bireylerin farklı işlevsel alanlardaki rolleri sabit zaman blokları içerisinde gerçekleşmez. Özellikle internet gibi teknolojiler sayesinde üretim, tüketim, eğitim, sosyal etkinlikler, özel ilişkiler gibi her türlü faaliyet her an ve her yerde gerçekleştirilebilme eğilimi içine girmiştir. Rosa (2013, s. 134) bu süreci "zamansal aynılaşma (temporal de-differentiation)" olarak nitelendirir. Bu süreçte, toplumsal sistemler, örgütlenmeler, kurumlar kendilerine daha çok zaman ayrılması konusunda daha talepkâr hale gelir; çünkü her bir alanda her zaman yapılacak daha fazla şey vardır. Bir alt sistemin perspektifinden diğer alt sistemlerdeki etkinlikler yalnızca işleri aksatan gecikmeler olarak görülür. Bazı sistemler diğerlerine göre aktörlerin zamanlarına erişme ve hâkim olma konusunda diğerlerine göre daha baskın olabilir. Aktörler farklı alanlardaki farklı toplumsal roller arasında belli ölçüde bir denge kurmaya çalışsa da bu duruma ayak uydurmak esnek bir zaman yönetimi ve farklı faaliyetler arasında sürekli bir gelgiti gerektirir (Rosa, 2013, s. 191-193).

\section{3. İşin ve İş Dışı Pratiklerin Zamansal Esnekleşmesi}

Gündelik yaşamdaki zaman baskısının ardında farklı boyutlarıyla sosyal hızlanma ve esnekleşme süreçlerinin olduğu düşünülebilir. Bireylerin daha fazla zamana sahip olma arzusu kendini özellikle iş dişı zamanda dişa vurur (Nowotny, 1994, s. 103). Ancak hızlanma ve esnekleşme koşullarında, daha fazla boş zamana sahip olma arzusu basitçe günümüz kapitalizminde hazza yönelik seçeneklerin artmasından ziyade daha temelde iş zamanının yayılmasına bir tepki olarak okunabilir. Çünkü çalışan bireyler zamanlarını nasıl kullanacakları, hangi etkinliği ne zaman yapacakları konusunda özgür değildir. Yüksek işsizlik oranlarının, düşük ücretlerin ve düşük 
sendikal mücadelenin söz konusu olduğu Türkiye gibi rekabetçi bir emek piyasasında istihdam edilebilirlik var olan çalışma rejimine büyük ölçüde boyun eğmeyi gerektirir. Dolayısıyla, günümüzde zaman baskısı esas olarak kapitalist çalışma koşullarından kaynaklanır ve bu baskıyı hafifletmek için çalışanlara bireysel olarak daha az çalışmalarını önermek mümkün değildir (Antonopoulos ve Memiş, 2010, s. 4-8; Zuzanek, 2004, s. 128). Bu çalışma bağlamında dile getirecek olursak, Rosa'nın bahsettiği hızlanma itici güçlerinden ekonomik olan kültürel olana göre daha baskındır.

Kapitalizmin ve kapitalist işletmelerin hızı farklı zaman birimlerinde dalgalanır. Bu dalgalanma günümüz kapitalizminin hızlanmasını esneklikle ilişkilendirebilmek için bir bağlantı noktasıdır. Kapitalizm için "vakit nakittir”. Ancak her zaman aralığı kârlılık için aynı derecede etkili değildir. Kapitalizmin döngülerinin hızlanması çizgisel bir süreç değildir. Hızın dalgalanması kârlılığa bağlıdır. Optimizasyonun sağlanması için zaman, sürekli göz önünde bulundurulan bir faktördür (Nowotny, 1994, s. 110-111). Günümüz hızlanma toplumu, çok yüksek hızla sürekli değişen koşullara ve artan belirsizliklere uyumu zorunlu kılmaktadır (Rosa ve Scheuerman, 2009, s. 11). Sosyal hızlanmanın farklı boyutları sebebiyle şirketlerin örgütsel yapısında dönüşümler olmakta, şirketler artık büyük ölçüde sabit "zaman blokları" prensibine göre çalışmamaktadır. İş yaşamında da önceden belirlenmiş, katı takvimler yerine esneklik ilkesi geçerlidir (Sennett, 2008, s. 59). Şirketler tarafından getirilen birçok yeni organizasyon ve yöntemin ortak özelliği ise şirket açısından hızlanma ve esnek birikim rejimine en verimli biçimde entegre olma çabasıdır. Kapitalizmin kurumsal unsurları sürekli ve hızlı bir değişim içindedir. Bu değişim sürekli ve hızlı bir uyumu zorunlu kılar. Kârlılık için hızlanılması gerektiğinde, üretim talepleri arttığında daha çok personelle daha çok iş yapılırken, talebin az olduğu ve hızlanmanın kâr getirmediği dönemlerde çalışanlara "boş yere" maaş vermek istemeyen şirketler bu personeli ya işten çıkarmakta ya da başka işlere yönlendirmektedir. Örneğin, "yıllık çalışma saati” formülü, haftalık çalışma gününe dayalı sözleşmeden farklı olarak, bir yılda bir çalışandan talep edilebilecek ortalama çalışma saati üzerinden yapılan bir sözleşmeyi ifade eder. Zamansal esnekliği şirketler lehine artıran bu uygulamaya göre çalışanlar, bir yılda çalışması gereken toplam saat dışında, çalışma zamanı açısından belirsizliğe itilir. Ne zaman çalışıp çalışmayacağı önceden belli olmasa da çalışan kişi resmî tatiller, geceler ve hafta sonları da dahil olmak üzere her an işe çağırılabilecekmiş gibi sürekli hazır olmalıdır (Bell ve Tuckman, 2002, s. 117, s. 121).

Şirketten şirkete ve çalışılan pozisyona göre farklılıklar görülse de genel olarak, çalışanların aynı anda birçok işi yürütmesi gerekir. Çalışanlar sürekli ve hızlıca iş yetiştirebilme baskı ve psikolojisiyle çalışır. Çoğu durumda çalışanlara mesai sürelerinde bitirilebilecek olandan çok daha fazla iş yüklenir ve çalışanların bu işleri bitirmeleri beklenir (Rosa, 2013, s. 168, s. 171-173; Sennett, 2008, s. 21-22). Bu yüzden işi sabahtan akşam üzerine kadar devam eden mesai saatlerinde tamamlamak mümkün olmaz. Çalışanların sözleşmelerinde işe giriş ve çıkış saatleri belli olsa da veya toplam mesai saatinde bir üst sınır konulmuş olsa da bunlara uyulmaz (Standing, 2011, s. 129). Günümüzde belli bir iş için belirlenen son tarihler, çalışma zamanı açısından sabit bir mesai saatinden daha belirleyicidir. Özellikle işlerinin tamamlanması gereken son tarihlere yaklaşıldığında mesai saatlerinin dişında ve bazen gece hiç uyumadan çalışma gereği doğar (Lee ve Liebenau, 2002, s. 135; Rosa, 2013, s. 136; Tietze ve Musson, 2002, s. 325). Hafta sonu kavram1, çalışmaya engel olabilecek bir sınır olmaktan çıkmıştır. Hatta resmi izin günlerinde ve resmi tatillerde çalışmak sıradanlaşmıştır (Bell ve Tuckman, 2002, s. 121; Tietze ve Musson, 2002, s. 325).

İş için özgülenmiş mekânlar varlığını sürdürse de ev gibi “özel alan”a en çok ait olan mekânlar bile iş yapılabilir yerlere dönüşebilmekte ve emek üzerindeki kontrol iş yeri mekânından ya- 
şamın diğer alanlarına da yayılmaktadır (Bell ve Tuckman, 2002, s. 119-120; Standing, 2011, s. 117, s. 126; Tietze ve Musson, 2002). Hem mesai günleri dışında hem de iş yeri dışında çalıştırılabilmenin altyapısını da teknoloji sağlamaktadır. Telefonlar ve çağrı cihazları ile başlayan iş yerinin fiziksel sınırlarının ötesinde "erişilebilir çalışan (accessible worker)"ın inşası süreci (Bell ve Tuckman, 2002, s. 118), hem iş yeri dışında ve her an çalışabilmeyi hem iş için sürekli erişilebilmeyi hem de yöneticilerin uzaktan denetimini daha rahat sağlayan internet temelli sanal ortamlar ve gelişen bilgi iletişim teknolojileriyle artarak devam etmektedir (Lee ve Liebenau, 2002, s. 128-129, s. 135). Çalışanlar kapitalizmin değişim hızına uyum sağlamalı ve bu uyum için süreklileşen bir çaba içinde olmalıdır. Söz konusu uyum çabası çalışanların giderek daha fazla "kaygan zeminler" üzerinde hakaret etmek zorunda olduklarını gösterir.

Günümüz kapitalist çalışma rejiminde çalışanların daha esnek yapılara uyum sağlaması, günün neredeyse her anı iş için erişilebilir olması ve hızlanmaya uyum sağlaması beklenir. Çalışanlar istihdam edilebilir kalabilmek için giderek hızlanır; yeterince hızlanamadıkları durumlarda işi mesai saatleri dışında tamamlamak zorunda kalır. Esneklik ve hızlanma talebi, işle ilgili alanlarda başlayıp iş dışı zamana sirayet eder. Esneklik ve iş için her an erişilebilir olma gerekliliği, planlanmış bir iş dışı aktiviteye engel olma veya onu bölme potansiyeli taşır (Bell ve Tuckman, 2002, s. 122). Tamamen ortadan kalkmasa da giderek silikleşen iş alanı ve iş dışı alan arasında hızlı bir şekilde gel-git yapabilen esnek bedenler olmadan bu talep tam olarak gerçekleştirilemez (Rojek, 2004, s. 56; Sennett, 2008). İş dış1 alan içerisinde kendine özgü bir yere sahip olan uyku da işte tam olarak böyle bir noktada önemli bir sorunsal halini alır. İş ve işle ilgili olan aktivitelerden geriye kalan vakit daraldıkça yaşamın diğer alanlarında da zaman baskısı ve hızlanma gereksinimi artar. Bu durum çalışanların hem uyku süresine hem de uyuma ve uyanma zamanlamalarına doğrudan etki eder. Kapitalizmin döngülerinin hızlanması, kapitalizmin soyut zamanıyla insan varoluşunun duygusal, öz-düşünümsel, sosyo-kültürel ve biyolojik zamansallıkları arasındaki gerilimin artmasına sebep olur (Jessop, 2009, s. 147). Çalışanlar giderek artan oranlarda zaman kıtlığı yaşamaktadır. Farklı etkinlikler arasındaki zamansal geçişler kısalır; birim zamana daha fazla etkinlik sıkışır. Zamanın yoğunluğu artar. Yoğunlaşan zaman içinde yaşamsal etkinlikler iç içe geçer ve aralarındaki uyum veya uyumsuzluklar belirginleşir. Uyanmadaki zorluk, kişinin kendisini uyanık kalmaya ve bazen uykusu olmamasına rağmen uyumaya zorlaması biyolojik ritimlerle sosyal yaşamın ritimleri arasındaki uyumsuzluk ve çatışmayı gözler önüne serer (Williams, 2014, s. 312-313). Bu sebeple hızlanma ve esnekleşmenin oluşturduğu zaman baskısının çıktılarından biri olan zaman kıtlığını yalnızca işin zorunluluklarına çok vakit ayırıp arzulanan etkinliklere az vakit ayırmakla ilgili olmadığını, aynı zamanda dinlenme ve uykuya az zaman ayırabilmekten kaynaklandığını belirtmek gerekir (Larsson ve Sanne, 2005, s. 217).

\section{Günümüz Kapitalizminde Uykunun Konumu}

Kapitalist sistem artı değeri garanti altına alabilmek ve artırabilmek için çalışanların bedenlerini belli ölçülerde kontrol etmeye çalışır (Harvey, 1989, s. 122). Bir çalışandan kâr elde edilecekse bedenin ve bu bedenin kapasitelerinin belli bir zaman disiplinine tabi olması gerekir. Çal1şanların zaman kullanımı doğrudan ya da dolaylı olarak şirketlerin zamanına göre düzenlenir. İşin gerektirdiği birçok koşulda, çalışanların uyuma ve hasta olma gibi "lüksleri” yoktur (Lee ve Liebenau, 2002, s. 128). Şirketler çalışanların zamanının büyük bir kısmını belli bir ücret karşı1ığı satın alır ve bu satın alınan zamanın boşa harcanmasına izin vermez. Bu durum yalnızca dar anlamıyla üretim alanı için değil aynı zamanda, mümkün olduğunca, ikincil ve üretimle doğrudan ilgili gibi görünmeyen etkinlikler için de geçerlidir. Çalışanın bedeni neyin ne zaman yapılıp 
yapılmayacağı konusunda yalnızca iş yerinde değil dolaylı olarak iş yeri dışındaki yaşamında da kontrol edilmeye çalış1lır (Inglis ve Holmes, 2000, s. 229-230). Zira iş dışı zamanda çalışanların neler yaptıkları iş yerindeki performanslarını ve verimliliklerini etkiler (Harvey, 1989, s. 123; Thompson, 1967, s. 61). Bir başka deyişle, çalışanlar kapitalizmin tanımladığı şekliyle "iyi bir yaşam" sürdürmelidir. Zamanlarını işin gerektirdiği oranda yoğun geçirmeli, sosyal ve ekonomik yaşamdan dişlanmalarına yol açacak yavaşlamalara sapmamalıdır.

Crary’e (2015, s. 24) göre günümüz kapitalizmi, 7/24 işleme zorunluluğundan ötürü, dinlenmeye, dolayısıyla çalışanların bir süre iş başında olmamasına giderek daha az tahammül etmektedir. Birçok sektör için çalışanların iş başında olmadığı herhangi bir vakit büyük kâr kayıpları anlamına gelir. Yeni küresel ekonomi 7/24 işleyen bir makinedir ve insanların uyuma gereksinimlerine ya da belli saatlerde uyumayı salık veren kültürel kodlara aykırı hareket eder (Standing, 2011, s. 115-116). Üretim ve tüketim açısından günün belli döngüleri, örneğin gece-gündüz ya da aydınlık-karanlık, arasındaki fark giderek azalır (Crary, 2015, s. 24). Günümüzde kapitalizm 7/24 işlemeye önceki dönemlerden daha elverişli olduğu için uyku giderek çalışma yaşamı için daha büyük bir "lüks" haline gelir. Diğer bütün yaşamsal etkinlikler gibi uykunun zemini de kayganlaşır. Uyku da hızlanmak zorundadır.

Bilgi ve iletişim teknolojilerindeki gelişmelerle ağlar üzerinden günün herhangi bir saatinde ve herhangi bir mekânda iş yapabilme olasılığ giderek artış göstermektedir; bu sebeple iş ve boş zaman, iş ve uyku zamanı ile boş zaman ve uyku zamanı arasında önceden az çok belirgin olan ayrımlar giderek silikleşmektedir (Crary, 2015, s. 25, s. 78). Uykusunun ortasında uyanıp mesaj ve e-postalarını isteyerek ya da mecburen kontrol eden ve gerektiğinde uykusuna ara verip iş yapan çalışanların sayısı giderek artmaktadır. Crary’e (2015, s. 23) göre, uyku tam da günümüzde birçok teknolojik ürünün çalışma özelliğine atıfla “uyku modu”nda gerçekleşir: tamamen kapalı olmayan, işin ve gündelik yaşamın gereksinimlerine her zaman hazır bir durumda, sürekli tetikte bir uyku. Zaman baskısı veya kıtlığı uykuyu özellikle işle ilgili etkinliklerle eşanlı var olmaya zorlar. "Uyku modu" bu eşanlılığın bir belirtisidir. Bu mod paradoksal olarak aynı anda hem uyuyor hem de uyumuyor olmayı ifade eder. Uyku, uyanıklık anındaki etkinlikler için şarttır. Öte yandan "uyku modu”nda olmayan "gerçek" bir uyku aynı etkinliklerin kesintiye uğraması anlamına gelir.

Crary'nin (2015) çalışması her ne kadar çok önemli tartışmaları, analizleri barındırsa ve önemli eğilimleri tespit etse de bazı aşırı genelleştirmelere düşmekte ve meselenin kimi boyutlarını ihmal etmektedir. Crary topyekûn bir hızlanma, uyku dışında her şeyi ele geçirmiş bir kapitalizm resmi çizmekte, birtakım çelişkileri ve farklı eğilimleri gözden kaçırmaktadır. Crary ayrıca, uykuyu romantikleştirmekte, onu kapitalist üretim ve tüketimden azade kalan tek temel alan gibi sunmaktadır. Crary, boş zamanı yalnızca kapitalizm için gerekli olan bir tüketim zamanı olarak resmeder. Buradan çıkacak sonuç uykunun kapitalizme karşı elde kalan tek direniş alanı olmasidir (Crary, 2015, s. 20-23, s. 122).

Crary'nin (2015) çalışmasında uyku süresinin azaltılması sosyal hızlanmanın kaçınılmaz bir sonucu ve daha fazla hızlanmayı sağlayan sebeplerden biri olarak görülür. Fakat bizce topyekûn bir hızlanma ve uyku dışında her şeyi ele geçirmiş bir kapitalizm resmi içinde kimi çelişkiler ve farklı eğilimleri gözden kaçırır. Örneğin, Crary (2015, s. 13-15), uykuyu ortadan kaldırmaya yönelik tıbbi çalışmaları ve bu çalışmaların kapitalizmle ilişkisini vurgulayarak uykunun ortadan kalkması durumunda kapitalist ilişki biçiminin daha fazla geçerli olacağını belirtir. Öte yandan, tıp disiplininin kapitalizmle büyük ölçüde iç içe geçmiş baskıcı ve problemli pozisyonuna rağmen, tıp günümüz kapitalizmine karşı eleştirel bir rol de oynayabilir. Zira sağlıklı uykuya dönük bazı tıbbi önerilere ancak kapitalizm dönüştürüldüğünde veya ortadan kaldırıldığında erişilebilir 
(Williams ve Wolf-Meyer, 2013, s. 12-14). Örneğin, sekiz saatlik tek parça düzenli gece uykusu sağl1klı kabul ediliyorsa günümüz çalışma rejiminin buna bir tehdit oluşturduğu söylemi üzerinden bir mücadele geliştirilebilir.

Kapitalizm karmaşık ve çelişkiler barındıran bir bütünlüktür. Crary’nin (2015) tespit ettiği eğilim büyük ölçüde geçerli olsa da uyku süresinin azaltılması aynı zamanda bazı koşullarda hızlanmanın önünde bir engel olabilir; hatta bazı yavaşlamalara bile sebep olabilir. Şirketler için, çalışanların daha az uyuması ve dolayısıyla daha çok çalışması arzu edilir bir şey gibi görünse de uykusuzluktan kaynaklanan iş kazaları, üretkenlikte azalma ve düşük performans kâr kayıplarına sebep olabilir (Williams ve Wolf-Meyer, 2013, s. 12). Örneğin, Amerika Birleşik Devletleri'nde uyku yoksunluğunun sebep olduğu üretkenlik kaybı ve sağlık hizmeti faturalarının şirketlere finansal maliyetinin toplam 41 milyar dolar olduğu tahmin edilmektedir (Chatzitheochari ve Arber, 2009, s. 33).

Crary (2015) kapitalizmin uykuyu ortadan kaldırmaya çalıştığını söyleyerek kapitalizmi totalleştirmektedir. Hâlbuki uyku ve uykuyla ilgili ürün ve pratikler üzerine örülmüş geniş bir ekonomik sektör mevcuttur. Aynı ekonomik sektör içerisinde farklı çıkarlar söz konusu olabilir. Örneğin bazı ilaç şirketleri insanların uyumamasını sağlamaya yönelik ilaçlar üzerine çalışırken bazıları da uyumakta zorlanan insanlar için uyku hapları üretmektedir. Uyku sağlığıyla ilgili ilaç sektörü, uyku pratiğini sağlıklı bir şekilde gerçekleştirmek üzere geliştirilmiş yatak, yastık, tekstil, aydınlatma sistemlerine dayanan sektörler, uyku konusuna değinen dergiler, bu alanda çalışmalar yürüten araştırma şirketleri uyku üzerinden kâr etmektedir. Kapitalizm bir yandan uykuyu sekteye uğratırken bir yandan da uykunun "garantörü" rolündedir (Williams, 2005, s. 165). Kapitalist iyi yaşamın zeminlerinden biri uykudur. Hatta uyku süresinin çalışma yaşamı tarafından tamamen baskılanması durumunda, tüketimde azalma olacağ 1 iddia edilebilir. Bu süreç kapitalizmin hızlanmasını sekteye uğratabilir ve istenmeyen yavaşlamalara sebep olabilir. Bu anlamda kapitalizm açısından uykunun sonlanması değil, hızlanması ve yoğunlaşması daha işlevsel olacaktır. Sosyal hızlanmanın baskısı altında veya onunla uyumlu olan bedensel pratikleri, özellikle de uyku deneyimini incelemek sosyal hızlanmanın somut analizi için gereklidir.

\section{Hızlanma-Yavaşlama Etkileşiminde Uykunun İkircikli Konumu}

Sosyal hızlanmanın dünyadaki herkesi etkilemediği, etkilediklerini de aynı şekilde ve aynı oranda etkilemediği bir gerçektir. Böylesi yekpare bir sosyal hızlanma sürecinden söz edilemez (Rosa, 2009, s. 94). Hızlanmanın da limitleri vardır; hatta hızlanma bazen yavaşlamalara sebep olabilir. Diğer yandan, bazen daha fazla hızlanabilmek için belli ölçülerde yavaşlamak gerekir. Hem makro hem de mikro düzeylerde hızlanmanın kendisini anlayabilmek için yavaşlamalara, sosyal yaşamın hızlanmayan, hızlanmaya direnen, hızlanma sonucu yavaşlayan yönlerine de bakılmalıdır. Bazı yavaşlamalar hızlanmaya tepkidir, bazıları hızlanmanın istenmeyen sonuçlarıdır, bazıları kaçınılmaz sonuçlarıdır, bazıları da hızlanma için gerekli yavaşlamalardır. Yavaşlamalar söz konusu olsa da sosyal hılanma kavramı günümüz toplumunun analizinde kilit önemini korumaktadır (Rosa ve Scheuerman, 2009, s. 6; Rosa, 2009, s. 81, s. 94-97, s. 108).

Rosa (2013, s. 84), sosyal hızlanma teorisinin bir parçası olarak, farklı yavaşlama formlarından söz etmektedir; bunlardan ilki "hılanmanın istenmeyen sonuçları (unintended consequences of acceleration)" olarak görülebilecek yavaşlamadır. İş dünyasının ve bunun için gerekli yeniliklerin hızına yetişemeyen şirketlerin iflası buna örnek verilebilir. Benzer şekilde, iş yaşamında beklenen hıza erişemeyen veya rekabetçi emek piyasasında hız açısından diğerlerinden geri kalan çalışanların istihdamdan dışlanması da hızlanma sürecinin bir çıktısıdır. Sonuç olarak 
uzun dönemli işsizlik çalışanların yaşamında göreli olarak aşırı derecede yavaşlamaya yol açar (Harvey, 1989, s. 147-148; Rosa, 2009, s. 94). Öte yandan, herkes ve her şey hızlandırılmaya çalışıldığında kazalar veya hatalar gibi istenmeyen yavaşlamalar söz konusu olabilir (Rosa, 2009, s. 94). Ayrıca daha fazla hızlanma senkronizasyon problemleri doğurabilir (Rosa, 2013, s. 84). Rosa'nın teorisinde ayrıca kasıtlı gerçekleştirilen yavaşlama formları mevcuttur. Bu kategoride yavaşlama, diğer süreçleri hızlandırmak veya hızlı toplumsal süreçlerde işleyebilmek ve daha fazla hızlanabilmek için gerekli olan kapasiteyi depolamak için kullanılan stratejileri ifade eder. Şirketler için küçülme, istikrarlı planlama, büyümeyi yavaşlatma gibi araçlar bu kategoriye girebilir. Birey düzeyinde meditasyon ve yoga bu kategoride yer alır. Benzer şekilde, kişisel gelişim kitaplarında iş yaşamında enerji ve yaratıcılığı artırabilmek için gönüllü olarak yavaşlama ve mola vermeye dair sayısız öneri mevcuttur (Rosa, 2009, s. 95; Rosa, 2013, s. 87-88). Tüm bunlar sonrasında daha fazla hızlanabilmek için geçici yavaşlama örnekleridir. Yavaşlama kapitalizmin hız11 akışından dışlanmamak amacıyla işlevselleştirilir.

Hızlanma ve yavaşlama hem kapitalizmin genel işleyişi hem de beden düzeyinde karş1lıklı etkileşim içindedir. Sosyal hızlanmanın bedensel bir boyutu vardır; çünkü hızlanma bedenin nasıl organize edildiğini ve bedensel pratiklerin nasıl şekillendiğini etkiler. Öte yandan bedensel yeterlilikler ve sınırlılıklar da sosyal hızlanmayı etkiler. Örneğin, bir bedenin düzgün bir şekilde işleyebilmesi için belli bir süre uyuması, dolayısıyla bu bedenin sosyal hızlanmadan bir ölçüde uzaklaşması gerekir. Bu anlamda bir bedensel pratik olarak uyku sosyal hızlanmanın farklı boyutlarını analiz edebilmek için iyi bir örnek oluşturur (Hsu, 2014, s. 214; Williams, 2014, s. 312). Belli bir tarihsel dönemdeki bedensel ritimleri anlamak o tarihsel dönemin kendisini anlayabilmek için önemlidir. Kapitalizm kendi içinde çelişkili bir sistemdir. Bedensel pratiklerdeki çelişkilerin sosyal ve sınıfsal analizi bu sistemdeki çelişkileri görebilmek adına işlevsel olabilir. Kapitalizm aynı zamanda kendi işleyişinin sürekliliği için farklı ritimler arasında bir uyumu tesis etmeye çalışır (Lefebvre, 2004).

$\mathrm{Bu}$ çalışmanın iddialarından biri, çalışanlar söz konusu olduğunda, uykunun ritimlerinin esas olarak işin ritimlerine göre düzenlendiğidir. Bir çalışan için kendi bedeninin ritimlerini, dolayısıyla uykusunu, işin ritimlerine göre ayarlamak, zaman ve beden disipliniyle bu ritimler arasında belli ölçülerde bir uyum yakalamak emek piyasasında kendine yer bulabilmek ve orada avantajlı kalabilmek için önkoşuldur. Japonya'da fabrikalara yakın yerlerde bulunan tren istasyonlarındaki "uyku çekmeceleri" uygulaması, üretimin hızlandığı dönemlerde ev ile iş arasındaki yolda harcanan zamanı azaltmayı hedeflemektedir. Üretimin gerekliliklerine göre çalışanların zamanları yeniden biçimlendirilir; böylece kazanılan zaman yeniden üretim için gereken uykudan daha az feragat edilerek üretime harcanan zamanın artırılması ve verimli kılınmasına yönlendirilir (Yılmaz, 2008, s. 163). Çalışanlar için, uyuma ve uyanmanın zamanlaması ile uyku süresi çoğunlukla işin gerekliliklerine göre ayarlanır. Çalışanların uyku üzerindeki bireysel kontrolleri sınırlıdır (Coveney, 2014, s. 129).

Hızlanma ve esnekleşmeyle uyumlu bir zaman-disiplini geliştiremeyen, yani bedenlerinin ritimlerini yeni çalışma rejiminin ritimleriyle uyumlulaştıramayan, hızlanma ve esnekleşmeden kaynaklı zaman baskısıyla mücadele edemeyen çalışanların rekabetçi emek piyasasında işlerini korumaları zorlaşır. Çalışanlar açısından sorun basitçe uyku süresini azaltmak değil, uykuyu hızlanma ve esnekleşmeden etkilenen yaşamlarında bir zaman-yönetimi konusu olarak ele alarak buna uygun bir zaman disiplini geliştirmektir. Çalışanlar ne zaman uyuyup ne zaman uyanacaklarının kararını her gün giderek artan oranda beklenmedik taleplere göre yeniden gözden geçirmek zorundadır. Kapitalizmin hızlı değişen çerçevesi uykunun zeminini kayganlaştırır. Kapita- 
list kurumlardaki değişimin çalışanlardan talep ettiği hızlı geri dönüşler uykunun öngörülebilirliğini azaltır. Uyku kendisine günün sabit bir zaman bloğunda yer bulamaz. Esnek çalışma saatleri, işin ve işle ilgili aktivitelerin günün önemli bir kısmına yayılması, iş yoğunlaşması, emek piyasasının serbestleşmesi, rekabet ve hızlanma gibi sebeplerden uyku, yaşamın uyanık kalınan bölümleri için feragat edilebilir, ertelenebilir, kısmen yok sayılabilir bir pratik haline gelir (Coveney, 2014, s. 124). Ancak bu uyku örüntüleri, Crary'nin (2015) istemeden de olsa yaptığ 1 gibi, toplumun tümüne genellenemez. Farklı toplumsal ve sinıfsal kesimlerin uyku pratikleri ve algılarında farklı sebepler ve süreçler etkili olmaktadır.

Böylesi hızlı bir dünyada, her ne kadar uyku bedensel ve zihinsel sağlık, beynin düzgün işleyebilmesi için zorunlu ve değerli kabul edilse de uykudan feragat etmek yaygın bir strateji olarak karşımıza çıkar (Coveney, 2014, s. 123). Uyku süresinin azaltılması ilk bakışta sosyal hızlanmanın bir gerekliliği olarak görünür. Bu azaltmanın amacı günümüz toplumunun ve çalışma rejiminin taleplerini yerine getirmektir. Bununla birlikte, daha önce belirtildiği gibi, yetersiz uyku işte verimliliğin düşmesine, kazalara ve hatalara, sosyal yaşamda iletişim bozukluklarına ve daha birçok soruna yol açarak tam da hızlanamamaya ve hatta yavaşlamaya sebep olabilmektedir (Hsu, 2014, s. 214-215). Dolayısıyla, iyi uyuyabilmek bir zaman yönetimi ve verimlilik stratejisine dönüşür. Bu yönüyle de uyku, Rosa'nın (2009, s. 96-97) kavramsallaştırmasıyla söyleyecek olursak, "daha çok hızlanabilmek için gereken yavaşlama (deceleration for further accceleration)" kategorisinde ele alınabilir. Sosyal hızlanma uykunun öngörülebilirliğini azaltırken, uykunun topyekûn öngörülemez bir konuma mahkûm edilmesi kapitalizmin kendi işleyişi açısından risk yaratır. Uyku, bir yavaşlama olarak, kapitalist hızlanmaya doğrudan karşıt bir süreç değildir. Kapitalist yapı içinde ortaya çıkan hızlanma süreçlerinin öngörülebilir düzeylerde tutulabilmesi, zaman baskısının ve kıtlığının yönetilebilir olabilmesi için uykunun hızlanma ve yavaşlama etkileşiminde anlamlandırılması gerekir.

Günümüzde uyku pratiklerinde yaşanan dönüşüm sürecini ve eğilimleri basitçe "uykuların sonu" olarak kavramsallaştırmak yerine "uykunun ikircikli konumu" olarak kavramak hem uykunun daha savunmasız hale gelmesi hem de eşzamanlı olarak daha çok önem kazanmasını birlikte gözlemleyebilmek için daha doğru olacaktır. Bu koşullar altında sağlıklı uykunun gerekliliklerini yerine getirmek çalışanların birincil önceliği değildir. Yine de çalışanlar sağlıklı uyumaya önem verir; çünkü ertesi gün işte kullanılacak olan fiziksel ve zihinsel kapasiteler için uyku gerekli görülür. Süre yönünden ciddi bir baskı altında oldukları için, çalışanlar sağlıklı uykunun süre gerekliliğini sağlamaya çalışmaktan çok diğer gerekliliklerini sağlamaya, süreyi değil kaliteyi artırmaya yönelir. Kaliteyi artırmak için uykunun gerçekleştiği ortamın koşullarını ses, ışık, sıcaklık ve temizlik yönünden rahat uykuya uygun hale getirmek, yatak, yastık gibi uyku materyallerini daha verimli bir uykuya göre seçmek gibi stratejiler uygulanır (Williams, 2002, s. 195). Bu anlamda, uyku da bir birim zamanda maksimum verimlilik hedefine yönelik olarak hızlandırılır. Uyku kapitalist değişimin kaygan zemininde yoğun, hızlı ve “uyku modu”nda gerçekleşmelidir.

\section{Sonuç}

Gündelik yaşamın giderek üzerine daha çok düşünülen bir konusu haline gelen uyku, aynı ilgiyi sosyal bilimlerden görememiştir. İnsanların yaşam süresinin neredeyse üçte birini kaplayan böylesine temel bir pratik, tıbbi araştırmaların birey temelli çalışma biçimi ve sorun çözme önerilerine ya da gazetelerin, dergilerin, popüler kişisel gelişim kitaplarının sağlık, verimlilik, zaman kullanımı stratejileri bağlamındaki önerilerine ve gündelik sohbetlerdeki yakınmalara terk edilmiştir. Tıp disiplinlerinde uykuya yönelik ilgideki artışın ve medyada bu konunun daha 
çok yer bulmasının ardında bazı sosyal dinamikler yatmaktadır. Bir eylemin ilk bakışta fizyolojik olması, onun toplumsallığını inkâr etmemize sebep olmamalıdır. Aksine, beden toplumsall1ğın görünür k1lındığ 1 , iktidarın üzerinde işlediği, ekonomik ilişkilerin üzerinde somutlaştı̆̆ 1 alanlardan biridir. Bir sosyallik içerisinde gerçekleşen ve bu sosyallikte yaşanan dönüşümlerden etkilenen bir pratik olmasına ek olarak, uyku üzerine geniş kapsamlı düşünmek ve uyku konusunu araştırmak bu dönüşümlerin bazı temel noktalarını aydınlatmaya yardımcı olacaktır. Beden, toplum ve bu ikisinin ilişkisi hem tarihseldir hem de çelişkilerle yüklüdür. Uykunun ritimleri kendiliğinden oluşmaz. Bedensel ritimlerin sosyallik içinde bir anlamı vardır. Bedenin, doğanın, kapitalizmin, gündelik yaşamın ritimlerinin birbiriyle nasıl etkileşim ve çelişki halinde olduğunu tartışabilmek için günümüzde sosyal hızlanmanın farklı boyutları ve çalışma rejimindeki esnekleşme göz önünde bulundurulmalıdır.

Sosyal hızlanma ve esnekleşmenin beraber ürettiği zaman baskısı uykuyu kapitalist iş süreçleri açısından işlevselleştirmeye çalışır. Kimi durumlarda ise uyku kapitalist üretim mekanizmaları önünde bir engel ve kâr kaybının nedenlerinden biri olarak görülür. Kapitalizmin 7/24 işleme eğilimi ve esnekleşme çalışanların uykularını ertelemesini veya bölmesini gerektirir. Süre sonlarına doğru işlerin yetişmesi riske girdikçe uyku tamamen engellenir ya da uykunun süresinin azaltılması talep edilir. Esnek çalışma rejimi düzenli bir uyku örüntüsü oluşturmayı engellediği için çalışanların uyumak istediğinde uyuyamamalarına sebep olabilmektedir. Fazla çalışma, iş stresi, rekabet, güvencesizlik, fiziksel ve zihinsel yorgunluk, ertesi günün planlanması gibi sebepler çalışanların uykularını olumsuz etkiler. Hızlanma ve rekabetçi emek piyasası işle ilgili vasıfların sürekli yenilenmesini ve çoğalmasını gerektirir. Söz konusu yenilenme mesai saatleri içerisinde yapılamadığ 1 için uyku süresinden feragat edilerek hayata geçirilir. Uyku ister istemez vasıf kazanmanın karşısına konumlandırılır ve bu anlamda değersizleştirilir. Öte yandan, çalışanlar işe geç kaldıklarında, uykusuzluk sebebiyle hızlı bir şekilde işleri tamamlayamadıklarında onlara iyi ve yeterli süre uyumaları tavsiye edilebilmektedir. Dolayısıyla uyku vasıf yenilenmesinin karşıtı gibi dururken, bedensel ve zihinsel emek gücünün yenilenmesinin koşulu olarak da sunulur. İşverenlerin uykuya karşı tutumu ikirciklidir; çalışanlarla olan ilişkilerinde iş ve uyku ikilisinin hangisinin öneminin vurgulanacağ 1 iş yerindeki duruma göre değişebilmektedir. Uyku bir yönüyle işin karşıtı iken, diğer yönüyle ayrılmaz parçasıdır.

Boş zaman çalışma ve uyku ilişkisine dâhil edildiğinde mesele biraz daha karmaşıklaşır. Uyku bir yandan kaybedilmekte olan, saldırıya uğrayan bir alandır ve korunmalıdır. Öte yandan uyku giderek artan şekilde zaman kaybı ve arzuları gerçekleştirmenin önünde bir engel olarak kodlanır. İş dışı zamanın tüm zorunlulukları ve istekleri, çalışmanın yaşamın büyük bir bölümünü işgal etmesinden ötürü kısa sürelere sıkışmak zorundadır. Böylesi hızlı bir dünyada, fazla uyumak arzulardan ve sosyal yaşamın gerekliliklerinden vazgeçmek demektir. Bu yüzden çalışanlar tatil günlerinde mümkün olduğunca az uyuma eğilimindedir. Fazla uyku, pişmanlı̆̆ tetikler. İnsanlar uyanık oldukları zamanlarda zaman baskısıyla mücadele edebilmek için stratejiler uygulasalar da birçok şeye yetişemezler; uykudan feragat önlerindeki yeni ve mecburi bir strateji olarak belirir. Bununla birlikte hem iş hem boş zaman aktivitelerinde daha iyi performans gösterebilmek yeterince uyumaya bağlıdır. Her iki durumda da uyku, uyumanın kendisi için yapılan bir etkinlik değil, uyanık olunan zamanın gereklilikleri, talepleri ve arzularına yönelik bir süreçtir. Çalışanlar, çoğu zaman yapmayı arzuladıkları şeylerden dolayı uykusuz kalıyormuş gibi görünseler de bunları uyku zamanından feragat etmeden yapamamalarının temel sebebi çalışma koşullarıdır. İş bir zorunluluk olduğu ve esnek çalışma rejimine tabi olan çalışanların yaşamlarını daha çok kaplama eğiliminde olduğu ölçüde arzulanan şeylere zaman ayırmak için feragat 
edilebilir alan olarak geriye uyku kalmaktadır. Esnek çalışma rejimi aslında katı bir zaman disiplinini gerektirmektedir. İşin gerekleri ve bu gereklerce kurgulanan çalışma zamanı esnetilemez katılıktadır. Bu katılaşmanın sürdürülebilirliği uyku rejiminin ve zamanının esnetilmesi sayesinde mümkün olur. İş azaltılabilir değildir; uyku ise esnek bir rejim içinde gerektiğinde azaltılıp gerektiğinde fazlalaştırılabilir. Bu kısıtlanmış, tanımı esnek fakat kendisi katı çerçeve içerisinde, çalışanlar için uyku ve uyanıklık bir tür "kendini-yönetme (self-management)" problemine dönüşür. Farklı stratejilerle uyanık kalma, uykuyu erteleme, uykunun gelmemesine rağmen uyumaya çalışma, gerektiğinde kısa süreli uyanıp tekrar uyuma, yeterli süre uyumamaya rağmen uyanmaya çalışma yönünde ciddi çabalar sarf edilmektedir. Kendini-yönetme problemi için geliştirilen bu cevapları uyku stratejileri olarak görmek mümkündür. Uyku stratejik olarak konumlandırılması ve yönetilmesi gereken bir süreçtir.

Uyku bir yönüyle Crary'nin (2015) tespit ettiği gibi baskılanan ve değersizleştirilen bir pratik olsa da günümüzde "uykuların sonu"nun geldiğini söylemek sürecin yalnızca bir boyutunu gösterir. Sürecin diğer boyutu ise eş zamanlı olarak çelişkili bir ilişkiye işaret eder. Uykusuzluğun hem işteki performansa hem de iş dışı zamandaki yaşama olumsuz etkilerinden kaçınmaya yönelik gittikçe artan bir ilgi söz konusudur. Sağlık söylemi tam bu noktada devreye girer. Bu tip söylemler uyku üzerinde süre ve zamanlama yönlerinden çok, uykunun gerçekleşeceği ortamın (ses, sıcaklık, ışık ve hijyen bakımından) ve uyku ile ilgili kullanılan materyallerin (yatak, yastık vb.) daha verimli bir uyku sağlaması hususunda etkili olmaktadır (Williams, 2002, s. 195). Sağlıklı uykunun zaman boyutu daha çok dışsal baskı altında olduğundan çalışanlar için geçerli olan hedef daha kısa sürede daha verimli uykudur. Daha verimli ve sağlıklı uyku kavramları etrafında örülmüş ciddi bir ekonomik sektör mevcuttur. Burada temel belirleyen sağlık söyleminin kendisi değil, maddi yaşamın koşullarıdır; sağlık söylemi bu koşullarla daha iyi mücadele edebilmek ve arzulara yer açabilmek için çalışanlar tarafından işlevselleştirilir.

Rosa'nın $(2009,2013)$ sosyal hızlanma teorisinde önemli olan hususlardan biri hızlanma kavramının yavaşlama kavramı ile karşılıklı etkileşimi içerisinde ele alınmasıdır. Hızlanma günümüzde baskın süreç olsa da yaşamın hiçbir alanında mutlak değildir. Hızlanma her sosyal olguyu ve her sosyal grubu aynı şekilde etkilemez. Uyku konusunda bahsedilen tüm bu süreç, Rosa'nın $(2009,2013)$ "daha çok hızlanabilmek için gereken yavaşlama” kavramına karşı1lık gelir. Uyku, uyanık olunan zamanın gereklilikleri ve arzularının hızına uyanık olunan zamanda yetişebilmek için gerekli olan yavaşlama olarak görülmektedir. "Hızlanma için yavaşlama" kapasitesi bu kadar açık olarak belki de sadece uykuda mevcuttur. Bu kapasite uykuyu belirgin bir çatışmanın hem öznesi hem nesnesi kılar. Sosyal hızlanma süreci bir yandan kendisi için de gerekli olan bu yavaşlamayı yeri geldiğinde yok sayma yönünde basınç oluştururken, bir yandan da benzer toplumsal süreçler bu yavaşlamayı daha verimli kılmaya yönelmektedir. Bu tip bir yavaşlamanın verimli kılınmadığı durumlarda verimsizlik, dikkatsizlik, kaza gibi "hızlanmanın istenmeyen bir sonucu olarak yavaşlama" ortaya çıkabilir. Bu türden bir yavaşlama hem çalışanlar hem de şirketler tarafından kaçınılan bir durumdur. Bu sebeple, bir bedensel pratik olarak uyku bir tür zaman disiplini ekseninde yeniden şekillendirilir. Bedenin yapısı ve yeterlilikleri hızlanmanın limitlerini etkilediği gibi hızlanma da bedensel pratikleri biçimlendirmeye çalışır. Bu biçimlenme özellikle yukarıda bahsedilen esnekleşme süreciyle paralel olarak, duruma göre şekil alması beklenen bir kalıp içerisinde gerçekleştirilir. Özetle uykunun "hızlanma için yavaşlama” kapasitesi keskinleştirilmeye çalışılır. İş ve iş dışı süreçlerin hızlanmanın egemenliği altında olduğunu düşünürsek, söz konusu keskinleştirmenin yavaşlamanın hızlandırılması anlamına geldiğini söyleyebiliriz. Verimli yavaşlama hızlandırılmış yavaşlama demektir. Fakat bu aynı zamanda iki karşıt sürecin 
birbirlerini sıkıştıracak şekilde daha kısıtlı bir zaman içinde hapsedilmesidir. Uyku giderek artan oranda söz konusu sıkışmanın zemini haline dönüşür.

$\mathrm{Bu}$ çalışma tüm bu tartışmalar üzerinden kapitalizmin gittikçe hızlanan soyut zamanıyla çalışanların biyolojik zamanları arasındaki artan gerilime odaklanarak yaşamın en bireysel gibi görünen aktivitelerden biri olan uykuyu ele almıştır. Uyku günümüz toplumunun zamansal yapıları ve çalışma rejiminin baskın özellikleriyle ilişkilendirilmiştir. Diğer bir deyişle, insan yaşamındaki en somut pratiklerden biri olan uykudan hareketle, yalnızca bu pratiğin kendisinin toplumsal konumunu değil aynı zamanda günümüz toplumunun temel yapılarına ve bunların ürettiği zaman deneyiminin kendisine dair bir analiz çerçevesi sunulmaya çalışılmıştır. Çerçevenin zemini zaman, odak noktası zaman baskısıdır. Zaman baskısı sosyal hızlanma ve esnekleşme süreçleri ilişkisine yerleştirilmiştir. Böylece çerçevenin üç sacayağı ortaya çıkmıştır. Uyku günümüz kapitalizmini tanımlayan bu üç unsurun ilişkisinde anlamlandırılmıştır. Bu anlamlandırma bağlamında uykunun hızlanma-yavaşlama etkileşiminde ortaya çıkan ikircikli niteliği makalenin temel savinı oluşturmuştur.

Çerçevede öncelikle Rosa'ya referansla sosyal hızlanmanın üç özelliği ve bu özelliklerin her biri ile eşleşen üç itici güç tanımlanmıştır. İtici gücü ekonomi olan teknolojik hızlanma birim zamana düşen üretimi artırmaya yöneliktir. Zamanın kapitalizmin dinamiklerine uygun olarak üretken kullanılmasını ifade eder. İtici gücü kültür olan yaşam temposunun hızlanması kapitalizmin tanımladığ “iyi yaşam”’ gerçekleştirmeye yöneliktir. Kapitalist kültürün ürettiği tüketilemez sayıdaki seçenek bireylerin yaşam tempolarını zorunlu olarak hızlanmaya zorlar. Kapitalist zaman süreklileşen bir zaman darlı̆̆ demektir. İtici gücü yapının kendisi olan toplumsal değişimin hızlanması kapitalist zamana zorunlu uyum anlamına gelir. Değişimin hızlanmış zamanına uyum sağlayamayan her şey ve herkes sistemden dışlanma riski ile karşı karşıya kalır. Sosyal hızlanmanın akabinde esnekleşme sürecine değinilmiştir. Esnekleşme aslen hızlanma ile paralel gelişir. Zira sosyal hızlanmanın zorunlu kıldığı kapitalist üretim tarzına uyumu tanımlar. Esnekleşme iş zamanı ile diğer zamanlar arasındaki sınırların belirsizleşmesi ve işin yaşamın diğer alanlarına sirayet etmesidir. Hızlanma ve esnekleşme birlikte zaman baskısını görünür kılar. Ekonomik, kültürel ve yapısal ayakları olan sosyal hızlanma ve sınırları silikleştirerek hızlanmaya eşlik eden esnekleşme ister istemez bireyin zamanını sıkıştırır ve bireyin zamanı üzerinde baskı yaratır. Bu baskının yansıyacağı ilk uğraklardan biri uykudur.

Sosyal hızlanma, esnekleşme ve zaman baskısı üçgenindeki sıkışmışlık uykunun günümüz kapitalizmindeki konumunu belirler. Uyku bir zaman disiplini meselesi olur. 7/24 işleyen kapitalizm diğer yaşam alanlarını olduğu gibi uykuyu da kendine tabi kılar. Uyku zamanı çalışma zamanına referansla tayin edilir. Fakat uykunun yaşamsal bir unsur olması bu tabiiyet ilişkisine ikircikli bir nitelik kazandırır. Daha az uyku görünürde daha çok çalışma ve daha fazla üretkenlik anlamına gelse de aynı zamanda daha fazla hata ve daha az üretkenlik anlamına da gelebilir. Bu ikircikli durum bir yavaşlama pratiği olan uykunun sosyal hızlanma-esnekleşme-zaman baskısı üçgenindeki hızlanma süreçleri ile etkileşiminde açığa çıkar. Her ne kadar hızlanma yavaşlama karşısında daha baskın olsa da uyku ve hızlanma arasında basitçe tek yönlü bir ilişkiden söz edilemez. Uyku kimi durumlarda hızlanmaya ket vurur, kimi durumlarda hızlanmayı destekler. Uykunun ikircikli konumunun önemli bir yansıması da uykuya atfedilen ikili anlamda belirginleşir. Uyku bir yandan yaşamın üretilmesi için zorunlu bir kaynak olarak anlam kazanırken, öte yandan yine aynı sebeple kendisinden vazgeçilebilecek ilk unsur olarak görülür. Uyku birebir aynı sebeple (yaşam üretimi) hem vazgeçilebilir hem de vazgeçilemez bir niteliğe sahip olur. Sonuç olarak, uyku kendisini bir yandan daha savunmasız ama öte yandan daha önemli, dolayısıyla ikircikli bir 
konumda bulur. Böylece uyku sosyal hızlanma, esnekleşme ve zaman baskısı üçgeninde sürdürülen sıkış(tırıl)mış yaşamları anlamak için zengin bir sosyolojik kavram haline gelir.

Hakem Değerlendirmesi: Dış bağımsız.

Yazar Katkıları: Çalışma Konsepti/Tasarım- E.K., Ç.T.; Veri Toplama- E.K., Ç.T.; Veri Analizi/Yorumlama- E.K., Ç.T.; Yazı Taslağı- E.K., Ç.T.; İçeriğin Eleştirel İncelemesi- E.K., Ç.T.; Son Onay ve Sorumluluk- E.K., Ç.T.

Çıkar Çatışması: Yazarlar çıkar çatışması bildirmemiştir.

Finansal Destek: Yazarlar bu çalışma için finansal destek almadığını beyan etmiştir.

Peer-review: Externally peer-reviewed.

Author Contributions: Conception/Design of Study- E.K., Ç.T.; Data Acquisition- E.K., Ç.T.; Data Analysis/Interpretation- E.K., Ç.T.; Drafting Manuscript- E.K., Ç.T.; Critical Revision of Manuscript- E.K., Ç.T.; Final Approval and Accountability- E.K., Ç.T.

Conflict of Interest: The authors have no conflict of interest to declare.

Grant Support: The authors declared that this study has received no financial support. 


\section{Kaynakça/References}

Antonopoulos, R., \& Memiş, E. (2010). Time and poverty from a developing country perspective. The Levy Economics Institute of Bard College Working Paper, 600, 1-37. Retrieved from http://www.levyinstitute.org/ publications/time-and-poverty-from-a-developing-country-perspective

Bell, E., \& Tuckman, A. (2002). Hanging on the telephone: Temporal flexibility and the accessible worker. In R. Whipp, B. Adam \& I. Sabelis (Eds.), Making time: Time and management in modern organization (pp. 115125). Oxford, UK: Oxford University Press.

Chatzitheochari, S., \& Arber, S. (2009). Lack of sleep, work and the long hours culture: Evidence from the UK time use survey. Work, Employment and Society, 23(1), 30-48. https://doi.org/10.1177/0950017008099776

Colley, H., Henriksson, L., Niemeyer, B., \& Seddon, T. (2012). Competing time orders in human service work: Towards a politics of time. Time \& Society, 21(3), 371-394. https://doi.org/10.1177/0961463X11434014

Coveney, C. M. (2014). Managing sleep and wakefulness in a 24 hour World. Sociology of Health \& Illness, 36(1), 123-136. https://doi.org/10.1111/1467-9566.12046

Crary, J. (2015). 24/7: Geç kapitalizm ve uykuların sonu (N. Çatlı, Çev.). İstanbul: Metis Yayınları.

Harvey, D. (1989). The condition of postmodernity. Oxford, UK: Blackwell.

Hsu, E. L. (2013). The sociology of sleep and the measure of social acceleration. Time \& Society, 23(2), 212-234. https://doi.org/10.1177/0961463X13486729

Inglis, D., \& Holmes, M. (2000). Toiletry time: Defecation, temporal strategies and the dilemmas of modernity. Time \& Society, 9(2-3), 223-245. https://doi.org/10.1177/0961463X00009002005

Jessop, B. (2009). The spatiotemporal dynamics of globalizing capital and their impact on state power and democracy. In H. Rosa \& W. E. Scheuerman (Eds.), High speed society: Social acceleration, power and modernity (pp. 135-158). University Park, PA: The Pennsylvania State University Press.

Kroll-Smith, S., \& Gunter, V. (2005). Governing sleepiness: Somnolent bodies, discourse and liquid modernity. Sociological Inquiry, 75(3), 346-371. https://doi.org/10.1111/j.1475-682X.2005.00126.x

Larsson, J., \& Sanne, C. (2005). Self-help books on avoiding time shortage. Time \& Society, 14(2-3), $213-230$. https://doi.org/10.1177/0961463X05055135

Lee, H., \& Liebenau, J. (2002). A new time discipline: Managing virtual work environments. In R. Whipp, B. Adam \& I. Sabelis (Eds.), Making time: Time and management in modern organization (pp. 126-139). Oxford, UK: Oxford University Press.

Lefebvre, H. (2004). Rhythmanalysis: Space, time and everyday life. S. Elden \& Gerald Moore (Çev.). London and New York: Continuum.

Marinache, R. (2015). Sleep: A sociological perspective. European Journal of Research on Education, 3(1), 17-29.

Mauss, M. [1932] (1973). Techniques of the body. Economy and Society, 2(1), 70-88.

Nowotny, H. (1994). Time: The modern and postmodern experience. Cambridge, UK: Polity Press.

Rojek, C. (2004). Postmodern work and leisure. In J. T. Haworth \&A. J. Veal (Eds.), Work and Leisure (pp. 51-66). London and New York: Routledge.

Rosa, H. (2009). Social acceleration: Ethical and political consequences of a desynchronized high-speed society. In H. Rosa \& W. E. Scheuerman (Eds.), High speed society: Social acceleration, power and modernity (pp. $77-$ 112). University Park, PA: The Pennsylvania State University Press.

Rosa, H., \& Scheuerman, W. E. (2009). Introduction. In H. Rosa \& W. E. Scheuerman (Eds.), High speed society: Social acceleration, power and modernity (pp. 1-29). University Park, PA: The Pennsylvania State University Press.

Rosa, H. (2013). Social acceleration: A new theory of modernity. New York, NY: Columbia University Press.

Rosa, H. (2017). De-synchronization, dynamic stabilization, dispositional squeeze. In J. Wajcman \& N. Dodd (Eds.), The sociology of speed: Digital, organizational, and social temporalities (pp. 25-41). Oxford, UK: Oxford University Press.

Roxburgh, S. (2002). Racing through life: The distribution of time pressures by roles and role resources among fulltime workers. Journal of Family and Economic Issues, 23(2), 121-145. https://doi.org/10.1023/A:1015734516575

Scheuerman, W. (1999). The economic state of emergency. Cardozo Law Review, 21, 1869-1894.

Sennett, R. (2008). Karakter aşınması: Yeni kapitalizmde işin kişilik üzerindeki etkileri (B. Yıldırım, Çev.). İstanbul: Ayrıntı Yayınları. 
Standing, G. (2011). The precariat: The new dangerous class. London and New York: Bloomsbury.

Šubrt, J., \& Cassling, R. (2001). The problem of time from the perspective of the social sciences. Czech Sociological Review, 9(2), 211-224.

Thompson, E. P. (1967). Time, work-discipline and industrial capitalism. Past and Present, 38 (December), 56-97.

Tietze S., \& Musson G. (2002). When 'work' meets 'home': Temporal flexibility as lived experience. Time \& Society, 11(2-3), 315-334. https://doi.org/10.1177/0961463X02011002008

Williams, S. J. (2002). Sleep and health: Reflections on the dormant society. Health, 6(2), 173-200. https://doi. org $/ 10.1177 / 136345930200600203$

Williams, S. J. (2005). Sleep and society: Sociological ventures into the (un)known, London and New York: Routledge.

Williams, S. J., \& Wolf-Meyer, M. (2013). Longing for sleep: Assessing the place of sleep in the $21^{\text {st }}$ century. Somatosphere: Science, Medicine and Anthropology, 19-22, 1-24.

Williams, S. J. (2014). The sociology of sleep and the measure of social acceleration: A rejoinder to Hsu. Time \& Society, 23(3), 309-316. https://doi.org/10.1177/0961463X14536483

Yılmaz, G. (2008). Kapitalizmde zaman-mekân sıkışması. Çalışma ve Toplum, 17(2), 155-172.

Yükseköğretim Kurulu Başkanlığı Tez Merkezi (2019). Retrieved from https://tez.yok.gov.tr/UlusalTezMerkezi/ giris.jsp

Zherebin, V. M., Vershinskaia, O. N., \& Makhrova, O. N. (2015). The modern perception of time and acceleration of the pace of life. Sociological Research, 54(3), 189-202. https://doi.org/10.1080/10610154.2015.1098297

Zuzanek, J. (2004). Work, leisure, time-pressure and stress. In J. T. Haworth \&A. J. Veal (Eds.), Work and Leisure (pp.123-144). London and New York: Routledge. 